\title{
Reflective Thinking Skill of Vocational High School Students
}

\author{
Dyah Ayu Sulistyarini \\ Mathematics Education Department \\ Sebelas Maret University \\ Surakarta, Indonesia \\ rinidyahayu@gmail.com
}

\author{
Imam Sujadi \\ Mathematics Education Department \\ Sebelas Maret University \\ Surakarta, Indonesia
}

\author{
Sri Subanti \\ Mathematics Education Department \\ Sebelas Maret University \\ Surakarta, Indonesia
}

\begin{abstract}
The aims of this research was to describe the characteristics of reflective thinking process of the students in Grade $X$ of Vocational High School of SMK Citra Medika Sukoharjo who have the high abilities in solving linear program problems. This research used qualitative case study approach. The data of research were gathered through task-based in-depth interview. The results of research were the characteristics of reflective thinking process of the students as follows the students with the high initial ability in Mathematics: (a) in the problem understanding phase, they were able to mention information of the problems and to explain what has been done; (b) in the problemsolving planning phase, they were able to identify the concept of the problems and to explain what has been done; (c) in the implementation of problem-solving plan phase, they were able to realize the mistakes and to fix them, to examine the truth of an argument, to employ the internal knowledge, to relate the information that they have known, and to communicate ideas with symbols instead of pictures or direct objects; and (d) in the reexamination phase, they were able to draw conclusions to return the answers back into the contexts and to explain what has been done.
\end{abstract}

\section{Keywords—reflective thinking; high ability}

\section{INTRODUCTION}

Learning Mathematics has an important role in education. Each level of education from primary school to college learn mathematics. Learning mathematics will not be separated from problem solving. Polya [1] in his book "How To Solve It" Polya presents two kinds of problems in mathematics: (1) Problem to find (problem to find), both theoretical and practical, abstract or concrete, including puzzles; and (2) Problems to prove (problem to prove), is to indicate one of the truths of the statement, whether a statement is true or false. Polya suggests four steps in solving the problem. The four steps are: (1) Understanding the problem (understanding the problem): (2) Thinking of a plan (devising a plan); (3) Implementing the plan (carrying out the plan); and (4) Looking back. Therefore, it is expected that learning mathematics in schools emphasizes not only give formulas also teach students to solve various mathematical problems.

One of the mathematical thinking which supports student problem solving abilities in learning mathematics is reflective thinking. This is related to the needs of students to solve problems faced in daily life. Gurol [2] thinks reflectively as a process of directional and precise activity in which individuals can realize, analyze, evaluate, and motivate in their own learning process. The reflective thinking process can reduce the error factor as students solve the problems they encounter. Whereas according to Choy [3] reflective thinking is an awareness of what is known and needed, it is very important to bridge the gap of learning situations.

Skemp [4] that reflective thinking process can be described as follows: (a) information or data used to respond, comes from within (internal), (b) can explain what has been done, (c) realize errors and fixes it, and (d) communicates ideas with symbols or images rather than direct objects. Chee [5] states that reflective thinking is an awareness of what is known and what is needed, it is very important to bridge the gap of learning situations. Kember, et al [6] explain based on Mezirow's theorical framework that reflective thinking can be divided into 4 steps, they are: (a) Habitual Action: a mechanical and automatic activity that is performed with little conscious thought. (b) Understanding: understanding is the student understands the situation without relates another situation. (c) Reflection: it is active, persistently and considering about the general truth of student consius. (d) Critical Thinking. Critical thinking is the highest thinking of reflective thinking that involves the student understands why do they feel various things. Decide and solve the problem.

The research conducted by Hepsi Nindiasari, et al [7] concerning the characteristics of reflective thinking processes of high school students are: (a) identifying mathematical concepts and / or formulas involved in non-simple mathematical problems; (b) checking the truth of an argument; (c) drawing analogies of two similar cases, (d) analyzing and clarifying questions and answers, (e) generalizing and analyzing them, and (f) distinguishing between relevant and irrelevant data.

Based on these results, the authors conducted research on the reflective thinking process of students with high mathematical ability on solving linear program problems.

\section{METHOD}

This research is a qualitative descriptive research that describes reflective thinking process of vocational students with high mathematics ability. Research subjects are 2 students who have high mathematical ability, with criteria of students have an expected ability, willing to be a subject, can communicate 
both oral and written and ask the teacher consideration. All data of interview result and written data, then analyzed for triangulation. Triangulation results will be validated to the results of interviews and then obtained the temporary results will be checked into related subjects to improve the validity of the data so that the conclusion in accordance with the data source.

\section{RESULTS AND DiSCUSSION}

In this research, at every stage of problem solving polya will be seen indicator reflective thinking. Reflective thinking indicators at the polya stage in this study will be shown in the table below.

TABLE I. REFLECTIVE THINKING DESCRIPTOR LINEAR PROGRAM Problem Solving, Based On Student Mathematic Ability

\begin{tabular}{|c|c|}
\hline $\begin{array}{c}\text { Steps In Polya } \\
\text { Problem } \\
\text { Solving } \\
\end{array}$ & Reflective Thinking Process Indicator \\
\hline $\begin{array}{l}\text { Understand the } \\
\text { problem }\end{array}$ & $\begin{array}{l}\text { 1. Able to explain the identification of facts } \\
\text { 2. Able to explain the identification of questions that } \\
\text { have been done well } \\
\text { 3. Able to the vocabulary that has been done well } \\
\text { 4. Able to explain about checking the adequacy of the } \\
\text { data already done } \\
\text { 5. Able to linking the identification of facts, question } \\
\text { identification, and adequacy of data with well- } \\
\text { informed information. }\end{array}$ \\
\hline $\begin{array}{l}\text { Plan Problem } \\
\text { Solving }\end{array}$ & $\begin{array}{l}\text { 1. Able to explain the compose and represent the } \\
\text { existing data well } \\
\text { 2. Able to explain about how to choose the } \\
\text { operation in solving the problem fraction well } \\
\text { 3. Able to explains about how to choose a solving } \\
\text { strategy, the subject does well }\end{array}$ \\
\hline $\begin{array}{l}\text { Implement } \\
\text { Problem-Solving } \\
\text { Plan }\end{array}$ & $\begin{array}{l}\text { 1. Have information about the calculation skill is } \\
\text { good enough, } \\
\text { 2. Have information about graphic drawing graph, } \\
\text { 3. Able to explain calculation which have done well } \\
\text { and accurate, } \\
\text { 4. Able to describes the graphics skills that have been } \\
\text { done well. }\end{array}$ \\
\hline Check Back & $\begin{array}{l}\text { 1. Able to explains whether the acquisition is close to } \\
\text { estimation, } \\
\text { 2. Able to explains whether the obtained it makes } \\
\text { good sense, } \\
\text { 3. Able to explains whether the obtained answer } \\
\text { answers the question well, } \\
\text { 4. Able to explains whether there is an error. }\end{array}$ \\
\hline
\end{tabular}

Based on the table above that has been studied, the researcher wants to explore the information through intense interview about the research subject understanding that relates with explaining linear program problem solving.

\section{A. The Analysis Results At The Stage Of Understanding The Problem}

The observations selected to describe the students' ability to understand the problem will be shown below:
TABLE II. The Analysis Results At The Stage OF UNDERSTANDING THE PROBLEM

\begin{tabular}{|c|c|c|}
\hline $\begin{array}{l}\text { Problem solving } \\
\text { phase }\end{array}$ & Subject 1 & Subject 2 \\
\hline $\begin{array}{l}\text { Understand the } \\
\text { problem }\end{array}$ & $\begin{array}{c}\text { T: Try to explain what } \\
\text { data is in the } \\
\text { question! } \\
\text { S: (students explain in } \\
\text { detail what data is } \\
\text { known from the } \\
\text { problem with its own } \\
\text { sentence) } \\
\text { T: Do you know what to } \\
\text { ask from the problem? } \\
\text { S: Yess Maam, look for } \\
\text { the minimum value } \\
\text { incurred to Maamy } \\
\text { liquid fertilizer and } \\
\text { tabor fertilizer } \\
\text { T: Previously have you } \\
\text { ever encountered a } \\
\text { problem like this? } \\
\text { S: Never Maam } \\
\text { T: Is there anything to } \\
\text { do with this matter? } \\
\text { S: The process of doing } \\
\text { it together Maam, } \\
\text { starting from creating } \\
\text { table, then mathematical } \\
\text { sentences, graphs, to test } \\
\text { point corner to find the } \\
\text { answers }\end{array}$ & $\begin{array}{c}\text { T: Try to explain what } \\
\text { data is in the question! } \\
\text { S: (students read the } \\
\text { question, can not } \\
\text { explain by its own } \\
\text { sentence) } \\
\text { T: what is the question } \\
\text { on the res? } \\
\text { S: the minimum cost } \\
\text { incurred for the } \\
\text { fertilizer } \\
\text { T: Previously have you } \\
\text { ever encountered a } \\
\text { problem like this? } \\
\text { S: Never Maam } \\
\text { T: Is there anything to } \\
\text { do with this matter? } \\
\text { S: determines the } \\
\text { mathematical model, } \\
\text { determines } \mathrm{x} \text { and y, } \\
\text { searches for completion } \\
\text { areas, graphs and tables }\end{array}$ \\
\hline
\end{tabular}

From the interview above, it shows that the students' reflective thinking in understanding the problem can be summarized as follows: 1) the subject can explain the identification of facts, 2) explain the identification of questions that have been done well, 3) explain the vocabulary that has been done well, 4) explain about checking the adequacy of the data already done, and 5) linking the identification of facts, question identification, and adequacy of data with wellinformed information.

\section{B. The analysis results at the planning stage of problem solving}

The observations selected to describe the students' ability to plan problem solving will be shown below: 
TABlE III. The Analysis Results at The Planning Stage of PROBLEM SOLVING

\begin{tabular}{|c|c|c|}
\hline $\begin{array}{l}\text { Problem } \\
\text { solving phase }\end{array}$ & Subject 1 & Subject 2 \\
\hline $\begin{array}{l}\text { Plan Problem } \\
\text { Solving }\end{array}$ & $\begin{array}{l}\text { T: when you get a } \\
\text { problem like this, what } \\
\text { comes to your mind first } \\
\text { to solve this problem? } \\
\text { S: Create a mathematical } \\
\text { table to describe and to } \\
\text { create graphs and } \\
\text { settlement areas } \\
\text { T: What are the } \\
\text { mathematical } \\
\text { calculations used to } \\
\text { solve the problem? } \\
\text { S: elimination, } \\
\text { multiplication of } \\
\text { functions to x and y } \\
\text { T: that's it? Any other? } \\
\text { S: it's Maam } \\
\text { T: had you ever a lesson } \\
\text { about the operation } \\
\text { before? } \\
\text { S: Yess Mom } \\
\text { T: when? } \\
\text { S: Then what does the } \\
\text { demolition do? } \\
\text { S: first create table then } \\
\text { translated to be used as } \\
\text { mathematical model, } \\
\text { from model used to look } \\
\text { for cut point and } \\
\text { settlement area, then test } \\
\text { corner point. If the } \\
\text { corner point is not } \\
\text { known, it will be } \\
\text { searched with } \\
\text { Maam } \\
\text { searched for the least } \\
\end{array}$ & $\begin{array}{l}\text { T: when you get this } \\
\text { question, what comes to } \\
\text { your mind first to solve } \\
\text { this problem? } \\
\text { S: create table Maam, to } \\
\text { look for x and y } \\
\text { T: What are the } \\
\text { mathematical } \\
\text { calculations used to } \\
\text { solve the problem? } \\
\text { S: linear operation } \\
\text { T: what kind of } \\
\text { linearity? } \\
\text { S: this one Maam } \\
\text { (denotes the intended } \\
\text { answer), looks for x zero } \\
\text { and y zero } \\
\text { T: is there something } \\
\text { else? } \\
\text { S: elimination Maam, } \\
\text { multiplication, } \\
\text { T: had you ever a lesson } \\
\text { about the operation } \\
\text { before? } \\
\text { S: emm, yes I never } \\
\text { Maam, Junior High } \\
\text { School } \\
\text { T: Then what does the } \\
\text { demolition do? } \\
\text { S: first create table, } \\
\text { liquid fertilizer e x, } \\
\text { fertilizer tabor eg y, } \\
\text { define mathematical } \\
\text { operations, specify } \\
\text { values of x and y, create } \\
\text { graph, specify } \\
\text { settlement area, test } \\
\text { corner point, find the } \\
\text { minimum value }\end{array}$ \\
\hline
\end{tabular}

Based on the description above, reflective thinking of the subject in planning solutions, there are several aspects that can be revealed: 1) the subject is able to explain the compose and represent the existing data well, 2) the subject can explain about how to choose the operation in solving the problem fraction well, and 3) The subject explains about how to choose a solving strategy, the subject does well.

\section{The Analysis Results At The Stage Of Implementing The Problem-Solving Plan}

The observations selected to describe the students' ability to implement problem-solving plan will be shown below:
TABLE IV. The AnAlysis Results at The Stage Of ImPLEMEnTing THE PROBLEM-SOLVING PLAN

\begin{tabular}{|c|c|c|}
\hline $\begin{array}{l}\text { Problem solving } \\
\text { phase }\end{array}$ & Subject 1 & Subject 2 \\
\hline $\begin{array}{l}\text { Implement } \\
\text { Problem-Solving } \\
\text { Plan }\end{array}$ & $\begin{array}{c}\text { T: Where to make a } \\
\text { graph from? } \\
\text { S: from mathematical } \\
\text { table count } \\
\text { T: sure of the } \\
\text { mathematics table? } \\
\text { S: (a little less sure) yes } \\
\text { ma'am. Eh no, from the } \\
\text { mathematics model } \\
\text { T: When do you use any } \\
\text { operation? } \\
\text { S: using the division } \\
\text { operation, multiplication, } \\
\text { elimination and enter the } \\
\text { value of x and y Maam, } \\
\text { do not know the term } \\
\text { T: okay okay. On this } \\
\text { answer, you have table } \\
\text { and graphic images. } \\
\text { What's that picture for? } \\
\text { S: From the mathematical } \\
\text { model you find the value } \\
\text { of x and y, continue to } \\
\text { find the completion area } \\
\text { using the graph } \\
\text { T: should it be with a } \\
\text { graphic image? } \\
\text { S: yes Maam (steady } \\
\text { voice when answering), } \\
\text { right to find the point of } \\
\text { cutting and settlement } \\
\text { area } \\
\text { M: when you answered, } \\
\text { do you make a mistake? } \\
\text { S: yes maam, this is } \\
\text { wrong (pointing wrong } \\
\text { answer) }\end{array}$ & $\begin{array}{c}\text { T: Where to make a } \\
\text { graph from? } \\
\text { S: from x and y values } \\
\text { found Maam } \\
\text { T: When do you use any } \\
\text { operation? } \\
\text { S: using the division } \\
\text { operation, } \\
\text { multiplication, } \\
\text { elimination and enter } \\
\text { the value of x and y } \\
\text { Maam, do not know the } \\
\text { term } \\
\text { T: On this answer you } \\
\text { have a table and graphic } \\
\text { images. What's that } \\
\text { picture for? } \\
\text { S: to search for corner } \\
\text { points and settlement } \\
\text { areas } \\
\text { T: when you answered, } \\
\text { do you make a mistake? } \\
\text { S: no Maam } \\
\text { T:sure? } \\
\text { S: yes ma'am } \\
\text { T: should it be with } \\
\text { tables and graphic } \\
\text { images? }\end{array}$ \\
\hline
\end{tabular}

Based on the description above, reflective thinking process in implementing the plan, it can be concluded that the subjects are: 1) have information about the calculation skill is good enough, 2) have information about graphic drawing graph, 3) explain calculation which have done well and accurate, and 4) describes the graphics skills that have been done well.

\section{Results of the analysis at the re-checking stage}

The observations selected to describe the students' ability to check back will be shown below: 
TABle V. Results of the Analysis at The Re-Checking Stage

\begin{tabular}{|c|c|c|}
\hline $\begin{array}{l}\text { Problem solving } \\
\text { phase }\end{array}$ & Subject 1 & Subject 2 \\
\hline Check Back & $\begin{array}{l}\text { T: approximately, your } \\
\text { final answer has made } \\
\text { sense yet, with the } \\
\text { purchase price of the } \\
\text { fertilizer as it is } \\
\text { known, then with your } \\
\text { final answer like that? } \\
\text { S: it's Maam } \\
\text { T: The answer you } \\
\text { found here, have you } \\
\text { answered the question } \\
\text { of the problem? } \\
\text { S: it's Maam, that's the } \\
\text { final answer } \\
\text { T: Try checking again, } \\
\text { is there still your fault? } \\
\text { S: oh, there's Maam, } \\
\text { the graph is wrong } \\
\text { (then the student } \\
\text { replaces with a more } \\
\text { appropriate answer } \\
\text { according to him) } \\
\text { T: has this been } \\
\text { changed more } \\
\text { precisely? } \\
\text { S: it's Maam } \\
\text { T: already convinced } \\
\text { by your final answer? } \\
\text { S: sure Maam }\end{array}$ & $\begin{array}{l}\text { T: approximately, your } \\
\text { final answer has made } \\
\text { sense yet, with the } \\
\text { purchase price of the } \\
\text { fertilizer as it is known, } \\
\text { then with your final } \\
\text { answer like that? } \\
\text { S: it's Maam } \\
\text { T: The answer you found } \\
\text { here, have you answered } \\
\text { the question of the } \\
\text { problem? } \\
\text { S: already } \\
\text { T: Try checking again, is } \\
\text { there still your fault? } \\
\text { S: There's no mistake } \\
\text { Maam } \\
\text { T: already convinced by } \\
\text { your final answer? } \\
\text { S: sure Maam }\end{array}$ \\
\hline
\end{tabular}

Based on what is described above, reflective thinking of the subject when solving the problem solving at the re-examining stage, it can be concluded that the subject as follows: 1) explains whether the acquisition is close to estimation, 2) explains whether the obtained it makes good sense, 3) explains whether the obtained answer answers the question well, and 4) explains whether there is an error.

\section{CONCLUSION}

Based on the result of the interview analysis above, it can be concluded to show that the students' reflective thinking ability in understanding the problem are: 1) the subject can explain the identification of facts, 2) explain the identification of questions that have been done well, 3) explain the vocabulary that has been done with good, 4) explains about checking the adequacy of data that has been done, and 5) linking fact identification, question identification, and adequacy of data with well-informed information. The ability to think reflectively the subject in planning the solution include: 1) the subject is able to explain the compose and represent the existing data well, 2) the subject can explain about how to choose the operation in solving the problem fraction well, and 3) the subject explains about how to choose the solution strategy, the subject did well. The ability of the reflective thinking process when implementing the plan can be summarized as follows: 1) having information on the calculation skills reasonably well, 2) having information about graphic drawing, 3) describing calculations that have been done well and accurately, and 4) charts that have been done well. The ability of the subject's reflective thinking when solving the problem solving at the re-examining stage, it can be concluded that: 1) explains whether the acquisition is close to estimation, 2) explains whether it is reasonable, 3) explains whether the answer answers the question well, and 4) explains whether there is an error. It is in accordance with Skemp [4] that reflective thinking processes can be described as follows: (a) information or data used to respond, coming from within, (b) being able to explain what has been done, (c) realize errors and correct them, and (d) communicate ideas with symbols or images rather than direct objects.

\section{REFERENCES}

[1] Polya, G. How To Solve It. Princeton: Princeton University Press, 1973

[2] Gurol, A.. Determining the reflective thinking skills of pre-service teachers in learning and teaching process. Energy Education Science and Technology Part B: Social and Educational Studies 2011, vol. 3, no. 3, pp. 387-402

[3] Choy, C.S dan Oo, P.S. Reflective Thinking And Teaching Practices: A Precursor For Incorporating Critical Thinking Into The Classroom? International Journal of Instruction, vol. 5, no. 1, hal. 1308-1470, 2012.

[4] Skemp, R, The Psychology of Learning Mathematics.USA. Peguin Books, 1982.

[5] Chee dan Pou. Reflective Thinking And Teaching Practices: A Precursor For Incorporating Critical Thinking Into The Classroom?. International Journal of Instruction. Vol 5. No 1, 2012 (e-ISSN: 1308-1470)

[6] Kember, D., Leung, D., Jones, A., Loke, A. Y., McKay, J., Sinclair, K., Tse, H., Webb, C., Wong, F. K. Y., Wong, M. \& Yeung, E. Development of a questionnaire to measure the level of reflective thinking. Assessment and Evaluation in Higher Education, 25, 381-389, 2000.

[7] Hepsi Nindiasari, Yaya Kusuma, Utari Sumarmo, dan Jozua Sabandar. Pendekatan Metakognitif untuk Meningkatkan Kemampuan Berpikir Reflektif Matematis Siswa SMA. Jurnal Ilmu Pendidikan dan Pengajaran, 2014, vol. 1, no. 1, hal. 80-90 